\title{
Design and Simulate an Off-Grid PV System with a Battery Bank for EV Charging
}

\author{
Mohamed Ahmed Mohamed ${ }^{1, *}$, Fatma Ahmed Mohamed ${ }^{2}$ \\ ${ }^{1}$ Department of Electrical and Electronic Engineering, Sohag University, Sohag 82749, Egypt \\ ${ }^{2}$ Faculty of Technology and Industrial Education, Sohag University, Sohag 82749, Egypt
}

Received May 28, 2020; Revised August 7, 2020; Accepted August 28, 2020

\begin{abstract}
Cite This Paper in the following Citation Styles
(a): [1] Mohamed Ahmed Mohamed, Fatma Ahmed Mohamed, "Design and Simulate an Off-Grid PV System with a Battery Bank for EV Charging," Universal Journal of Electrical and Electronic Engineering, Vol. 7, No. 5, pp. 273 - 288, 2020. DOI: 10.13189/ujeee.2020.070502.
\end{abstract}

(b): Mohamed Ahmed Mohamed, Fatma Ahmed Mohamed (2020). Design and Simulate an Off-Grid PV System with a Battery Bank for EV Charging. Universal Journal of Electrical and Electronic Engineering, 7(5), 273 - 288. DOI: 10.13189/ujeee.2020.070502.

Copyright $\subseteq 2020$ by authors, all rights reserved. Authors agree that this article remains permanently open access under the terms of the Creative Commons Attribution License 4.0 International License

\begin{abstract}
This paper presents the control and design of a stand-alone photovoltaic (PV) system with a battery bank for an electric vehicle (EV) battery charging. It also describes the necessary requirements and power electronic converters design for the EV battery charging station. The design of a bidirectional converter to allow for bidirectional power flow control to regulate the charging and discharging of the battery bank is presented. The PV system connected to the battery bank system is used to enhance the power output of renewable energy sources, regulate electrical power to effectively charge batteries, draw maximum power from solar panels, and provide a high-quality DC output for electric vehicle charging. The PV is the primary power source of the system, and a battery bank is used as a backup storage system. A comparison between the performance both of lithium-ion batteries and lead-acid batteries based on using it as a backup storage system for the off-grid PV system is presented. The proposed system has been designed and simulated in the MATLAB-Simulink environment. The effective performance of the proposed station for EV battery charging is achieved through the simulation results. A proposed charging station cost estimation is performed to present a powerful index of the proposed charging station's effectiveness.
\end{abstract}

Keywords EV Charging Station, Stand-Alone PV System, Battery Bank, Solar Cells

\section{Introduction}

With the continual increase of environmental worries, countries of the world have made many standards for carbon emissions. Electric vehicles (EVs), which fundamentally depend on electricity, have the chance to replace traditional gasoline and diesel vehicles. EVs provide an efficiency increase in energy savings through effective fuel economy, particularly when the electricity is produced from renewable resources, like solar and wind. Several suggestions have been made when dealing with EVs in smart grids, which are not just an electrical load, but as a power resource [1-3]. A methodology for modeling EV as an extra load on the distribution network was proposed in [4-10]. Many researchers introduced the grid-connected PV system for EVs charging [11-14]. Generally, the grid-connected system does not need a backup battery. The grid-connected system has two configurations. The first: the PV system participates with the utility grid in supplying the load with energy. This means that the PV system power is often less than the power required for the load. The second: the PV system is designed to supply the load with the required power and the utility grid in this configuration is a backup source during solar power fluctuations. With the continuous growth of demand for using EVs, it became necessary to increase charging stations. EVs need a large number of charging stations. Thus, EVs will be a significant burden on the distribution network system in the future. The 
off-grid PV system or standalone PV system term means the system has no connection to the main grid. Off-grid systems are appropriate for the electrification of small societies and it is feasible for remote areas. Off-grid systems are suitable for EV charging stations in faraway roads. Many papers presented the off-grid system design [15-17]. For facing renewable power fluctuations, the control of the charging process of $\mathrm{EV}$ has been discussed in [18-20]. In [21] introduces EV fast-charging technologies. Banks of backup batteries are used most mainly for the off-grid system for energy storage [22-23]. A comparison between Lead-Acid and Lithium-Ion Batteries for energy storage in off-grid energy systems is presented in [24]. In [25] shows a study of the backup battery charging control techniques for PV systems. This controller maintains the good advantages and solves the drawbacks and restrictions of the conventional controllers. Lithium-ion batteries [26] are one of the best energy storage systems because of the many advantages of high storage capacity, and therefore the solar charging station is a fully renewable energy system. In this case, the PV-Battery Energy Storage System needs a good controller to regulate the charge and discharge of the battery bank.

\subsection{Contribution of This Paper}

The present paper describes a very practical approach in designing a model of a charging station of electric vehicles shown in Fig. 1 consists of an off-grid system with a battery bank.

In a simple way, the principal contributions of this paper may be described as follows:
1. The present work offers an environmentally-friendly charging station model for charging electric vehicles that suit remote areas far from the utility grid.

2. The design of the proposed charging station in step by step is explained.

3. DC-DC converters design used for the proposed charging station is presented to ensure the best performance.

4. The effectiveness test of the logic controller for the bidirectional converter [27-28] is done to regulate the charge and discharge of the battery pack.

5. The performance test of the lithium-ion batteries and the lead-acid batteries as an energy storage system for the proposed charging station.

6. A practical approach in cost estimation of the proposed charging station is carried out.

\subsection{The Organization of This Work}

The rest of the paper is documented in the following order. Section 2 presents the estimation of the required charging power of an electric vehicle. The back-up batteries' storage capacity and the sizing of the PV system are calculated in sections 3 and 4 respectively. Section 5 displays the design of the boost converter, the buck converter, and the bidirectional converter. A summary of the parameters that are used and that are calculated is listed in section 6 . The charge and discharge controller modes for the battery pack are described in section 7 . Section 8 discusses the simulation results. The performance of the lithium-ion batteries and the lead-acid batteries with the proposed charging station is shown in section 9. Finally, the proposed charging station cost is estimated in section 10.

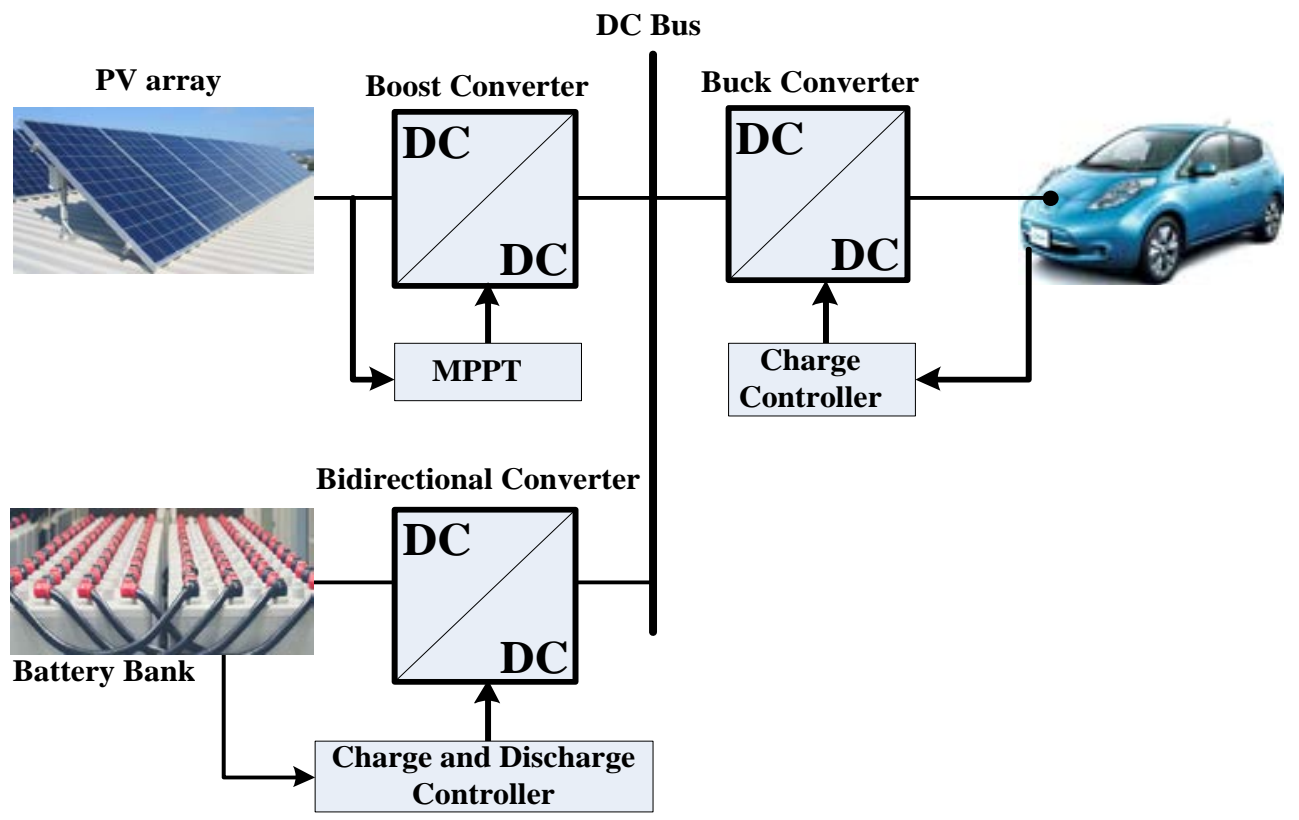

Figure 1. The proposed charging station for an electric vehicle 
Table 1. Charging time and standards according to IEC 61851-1

\begin{tabular}{|c|c|c|c|c|}
\hline \multirow{2}{*}{ Network Connection } & $\begin{array}{c}\text { Ordinary charging } \\
1 \text {-phase }\end{array}$ & $\begin{array}{c}\text { Ordinary charging } \\
\text { 3-phase }\end{array}$ & \multicolumn{2}{|c|}{ Fast and extremely fast charging } \\
\cline { 2 - 5 } & $\begin{array}{c}\mathrm{V}=230 \mathrm{~V} \mathrm{AC} \\
\mathrm{I}=16 \mathrm{~A} \\
\mathrm{P}=3.7 \mathrm{~kW}\end{array}$ & $\begin{array}{c}\mathrm{V}=400 \mathrm{~V} \mathrm{AC} \\
\mathrm{I}=32 \mathrm{~A} \\
\mathrm{P}=22 / 43 \mathrm{~kW}\end{array}$ & $\begin{array}{c}\mathrm{V}=500 \mathrm{~V} \mathrm{AC} \\
\mathrm{I}=250 \mathrm{~A} \\
\mathrm{P}=220 \mathrm{~kW}\end{array}$ & $\begin{array}{c}\mathrm{V}=600 \mathrm{~V} \text { AC } \\
\mathrm{I}=400 \mathrm{~A} \\
\mathrm{P}=240 \mathrm{~kW}\end{array}$ \\
\hline Battery $(\mathrm{kWh})$ & \multicolumn{4}{|c|}{ Charging Time } \\
\hline 100 & $27 \mathrm{~h}$ & $2.5 / 4.5 \mathrm{~h}$ & $30 \mathrm{~min}$ & $25 \mathrm{~min}$ \\
\hline 40 & $11 \mathrm{~h}$ & $60 / 120 \mathrm{~min}$ & $10 \mathrm{~min}$ & $10 \mathrm{~min}$ \\
\hline 20 & $5.5 \mathrm{~h}$ & $30 / 60 \mathrm{~min}$ & $5 \mathrm{~min}$ & $5 \mathrm{~min}$ \\
\hline 10 & $3 \mathrm{~h}$ & $15 / 30 \mathrm{~min}$ & $<5 \mathrm{~min}$ & $<5 \mathrm{~min}$ \\
\hline
\end{tabular}

\section{The Required Charging Power of the Electric Vehicle}

There are diversities of charging technology for EVs and various charging standards (both in terms of power and time). Table 1 shows the rating of the charging standards, according to IEC (International Electrotechnical Commission) 61851-1.

To achieve the least charging time of EV battery, enough large power chargers are essential, which follows physics fundamental laws: $P_{C h}=E / t_{c h}$, where: $P_{C h}-$ charger power in W, $E$ - battery energy in watt-hour, $t_{c h}$ - charging time in h. Thus, for instance, to charge $100 \%$ of the $100 \mathrm{kWh}$ battery (Tesla S 100D cars) in 20 $\mathrm{min}$, the required charger power is $300 \mathrm{KW}$.

\section{Specifying the Battery Storage Capacity of the Off-Grid System}

Batteries are the main component of off-grid systems. The storage battery supplies the load with the required power during the night and cloudy weather periods or with the participation of the PV system during limited sunlight intervals. The periods in which the system doesn't depend on energy generated by PV modules are known as 'days of autonomy'. Days of autonomy $\left(N_{C}\right)$ usually are 4 days.

Other parameters are taken into account when calculating storage capacity:

$\boldsymbol{E}=$ the electric vehicle battery power, i.e. $100 \mathrm{kWh}$ battery (Tesla S 100D cars) which is chosen as a load to design the proposed charging station.

$\boldsymbol{D O D}=$ Upper limit allowable depth of the battery bank discharge i.e. 0.8 .

$V_{\boldsymbol{S S V}}=$ Storage system voltage, i.e. $400 \mathrm{~V}$.

$\boldsymbol{\eta}_{\boldsymbol{B}}=$ Battery bank efficiency, i.e. 0.85 .

Consequently, the storage capacity of the battery bank $(B B C)$ can be calculated by the following relation [29]:

$$
B B C=\frac{N_{C} E}{D O D \eta_{B} V_{S S V}} \simeq 1500 \mathrm{Ah}
$$

ODM Deep Cycle 48 Volt Lithium Li-ion 200Ah Lifepo4 48V Battery Pack is chosen.
The total number of the required batteries $\left(N_{B t}\right)$ :

$$
N_{B t}=\frac{B B C}{200 A h} \approx 8 \text { batteries }
$$

Number of batteries in series $\left(N_{B s}\right)$ :

$$
N_{B S}=\frac{V_{S S V}}{48 V} \approx 8 \text { batteries }
$$

Number of batteries in parallel $\left(N_{B p}\right)$ :

$$
N_{B p}=N_{B t} / N_{B s}=1 \text { battery }
$$

\section{Sizing of PV Array}

The major steps which are necessary for determining an off-grid PV system sizing as the following:

1. Deciding the nominal operating voltage of the PV system $\left(V_{D C-l i n k}\right)$.

The nominal Voltage i.e., $V_{D C-l i n k}=600 \mathrm{~V}$ is chosen for the design.

2. Specify the total load current.

The total load current is the sum of both the charge current required for the electric vehicle battery and the charging current required for the battery bank. The charger power is $300 \mathrm{KW}$ and $V_{D C \text {-link }}$ is $600 \mathrm{~V}$ consequently; the charge current $\left(I_{C G B}\right)$ is $500 \mathrm{~A}$. The battery bank storage capacity is $1500 \mathrm{Ah}$ and the charging current of the storage system $\left(I_{C G S}\right)$ is almost $20 \%$ of the battery bank capacity, i.e. $300 \mathrm{~A}$. The total charge current is $800 \mathrm{~A}$.

3. System losses are added.

The consumed energy by the system components is system losses. Consequently, the required total current, which was specified in step 2, is increased with 20 for system losses compensating. The total current $\left(I_{T C}\right)$ after adding the system losses is approximately $1000 \mathrm{~A}$.

4. Determining the number of PV modules.

In the best arrangement of the panels, the required total PV array load in ampere (as shown in step 3) is got with the least number of panels. The solar array is formed of modules that are connected either in parallel or in series. 
The demanded number of panels in parallel $\left(N_{P}\right)$ is computed by dividing the whole current demanded from the solar array (shown in step 3) by the current generated by the panel at maximum power $\left(I_{m p}\right)$ shown in Table 2 . Consequently, $N_{P}$ is almost 180 modules. $N_{S}$ (The number of modules in series) is calculated by dividing 600 $\mathrm{V}\left(V_{D C-\text { link }}\right)$ by the nominal panel voltage $\left(V_{m p}\right)$ shown in Table 2. Thus, $N_{S}$ is approximately 11 modules. The total number of modules is $N_{t}=N_{S} * N_{P}=1980$.
Table 2. SunPower 305-SPR-WHT Module datasheet

\begin{tabular}{|c|c|c|}
\hline Peak Power (+/-5\%) & $P_{\max }$ & $305 \mathrm{~W}$ \\
\hline Rated Voltage & $V_{m p}$ & $54.7 \mathrm{~V}$ \\
\hline Rated Current & $I_{m p}$ & $5.58 \mathrm{~A}$ \\
\hline Open Circuit Voltage & $V_{O C}$ & $64.2 \mathrm{~V}$ \\
\hline Short Circuit Current & $I_{S C}$ & $5.96 \mathrm{~A}$ \\
\hline
\end{tabular}

Figs. 2 and 3 present the P-V and I-V curves at different irradiances and various temperatures.
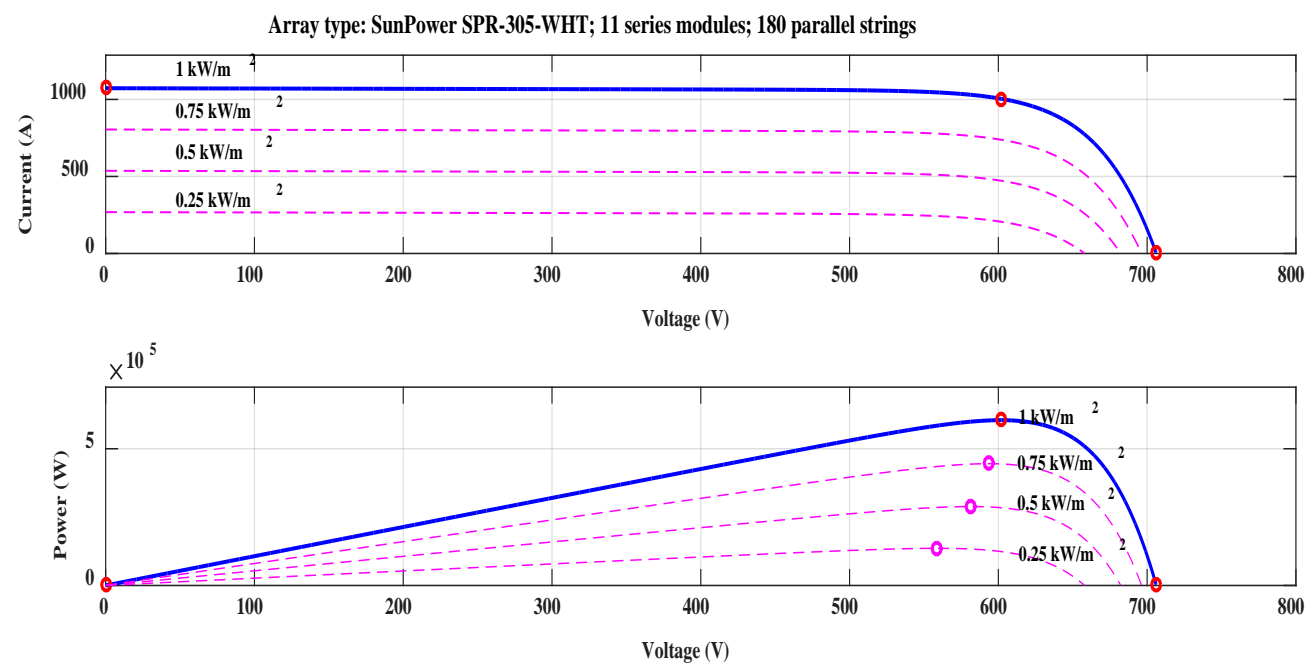

Figure 2. The $\mathrm{I}-\mathrm{V}$ and $\mathrm{P}-\mathrm{V}$ curves of the $\mathrm{PV}$ array at various irradiance and $25^{\circ} \mathrm{C}$ temperature
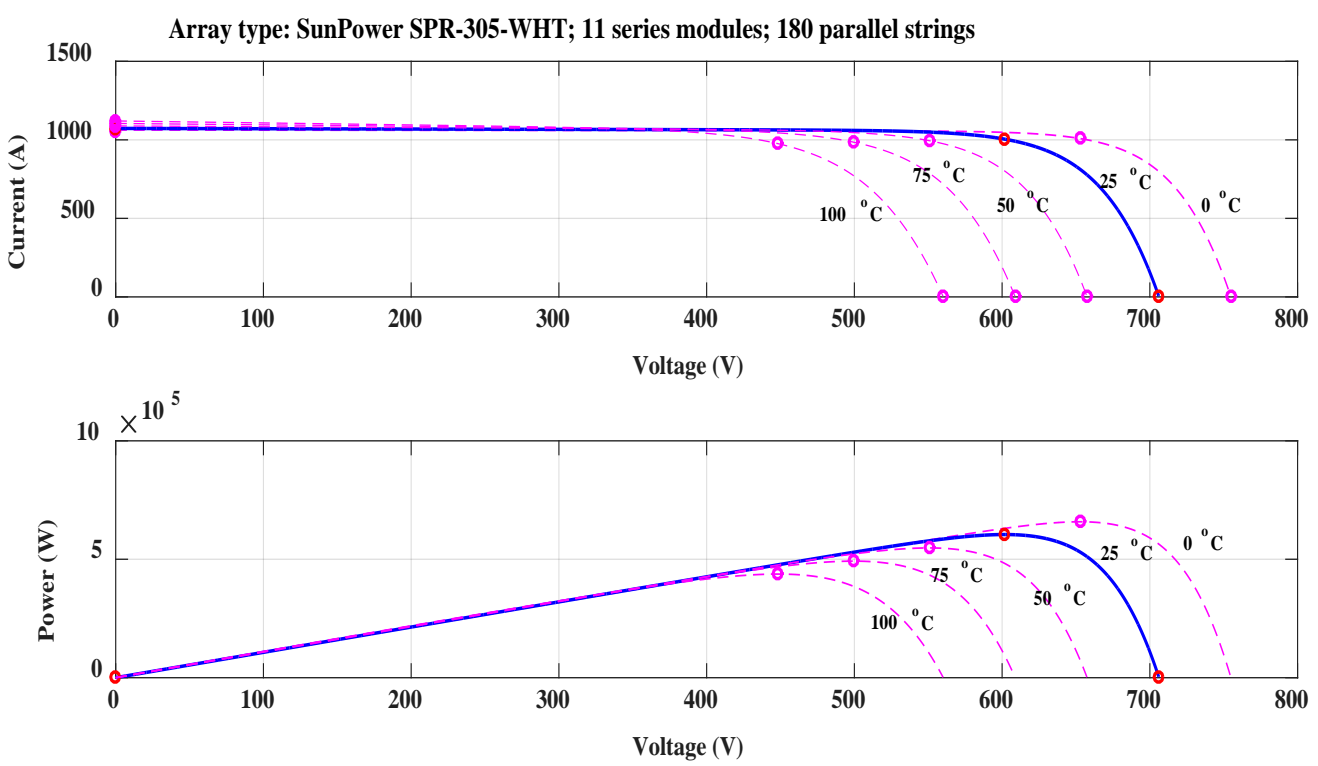

Figure 3. The $\mathrm{I}-\mathrm{V}$ and $\mathrm{P}-\mathrm{V}$ curves of the PV array at various temperatures and irradiance of $\mathrm{KW} / \mathrm{m}^{2}$ 


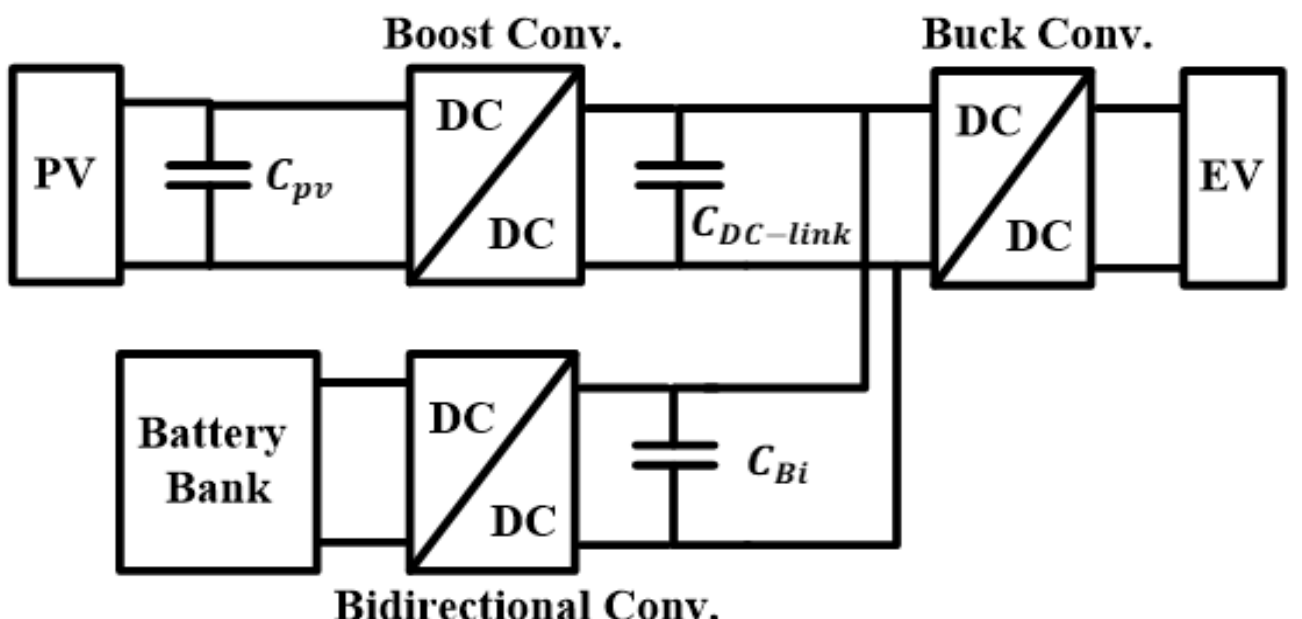

Figure 4. The proposed charging station diagram

\section{Design the Proposed Charging Station Converters}

The essential technology linked with PV systems is the power converter. A perfect PV power converter should drag the maximum power from the PV module and provide it to the load. For the grid-connected systems, this should be achieved with the least harmonic content in the current and at a PF (Power Factor) value is higher than 0.9. In the off-grid systems, the output voltage should also be adjusted to the required value. Three DC-DC converter topologies are used for the proposed charging station shown in Fig 4. The boost converter is used to convert the variable voltage from the modules into a stable voltage while the buck converter is used to reduce the DC Bus voltage to the electric vehicle battery voltage. The bidirectional converter is used to regulate both the charging and discharging of the battery bank.

The design of three DC-DC converters is described below.

\subsection{DC-DC Boost Converter}

The boost converter is shown in Fig. 5 [30] is composed of the voltage of the PV modules as the input source $\left(V_{p v}\right)$, boost inductor $\left(L_{B o o s t}\right)$, DC-link capacitor $\left(C_{D C \text {-link }}\right)$, a diode $(D)$, MOSFET (Metal-Oxide-Semiconductor FieldEffect Transistor) $(S)$ as a switch and the output voltage $\left(V_{D C \text {-link }}\right)$ (DC Bus Voltage). The output voltage of the boost converter is higher than the input. By modifying the duty cycle of the MOSFET, control or the modifying of voltage can be done.

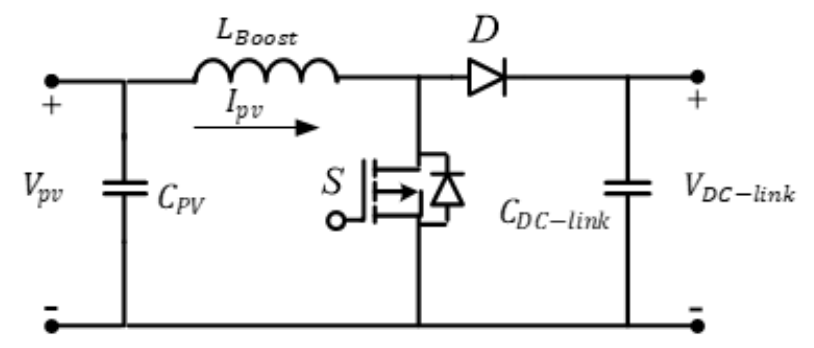

Figure 5. The Boost Converter diagram

The output voltage $V_{D C \text { link }}$ is related to the input voltage $V_{P V}$ according to the following equation [30]:

$$
D=1-\frac{V_{P V}}{V_{D C-l i n k}}
$$

Where $\mathrm{D}$ is the duty cycle.

To calculate the duty cycle of the boost converter, Eq (2) is used. Through the simulation, solar radiation varies from 0 to $1000 \mathrm{~W} / \mathrm{m}^{2}$ and temperature varies from 25 to $75^{\circ} \mathrm{C}$.

The boost converter duty cycle is determined for a cell temperature of $25^{\circ} \mathrm{C}$ and irradiance of $1000 \mathrm{~W} / \mathrm{m}^{2}$. As noticed from Figs. 3 and 4, $V_{P V}=600 \mathrm{~V}$. $V_{D C \text { link }}$ is equal to $600 \mathrm{~V}$ which gives, $D_{600 \mathrm{~V}}=1$.

During the irradiance $1000 \mathrm{~W} / \mathrm{m}^{2}$ and at the temperature $100^{\circ} \mathrm{C}$, the total modules' voltage decreases to $448 \mathrm{~V}$, as noticed in Fig. 3. Therefore, the duty cycle should be decreased to obtain the required DC-link voltage. The computed value of the duty cycle using Eq. 2 is,

$$
D_{448 V}=0.253
$$

The change in the array voltage $\left(\Delta V_{P V}\right)=(600 \mathrm{~V}-448 \mathrm{~V})$ $=152 \mathrm{~V}$. 
The increase and decrease of the power and voltage of the array are checked by applying the Perturb and Observe Algorithm [31] for MPPT using the direct duty cycle control method.

\subsubsection{Design of Boost Inductor and PV Array Capacitor}

The inductance for continuous current in the boost converter is calculated as follows [30]:

$$
L_{\text {Boost }}=\frac{V_{I N}\left(V_{D C-l i n k}-V_{I N}\right)}{\Delta i_{L-B o o s t} f_{S w} V_{D C-l i n k}}=16.3 \mu \mathrm{H}
$$

$f_{s w}$ is the switching frequency which is chosen to be 40 $\mathrm{kHz} . \mathrm{V}_{\mathrm{IN}}$ is the converter input voltage $=448 \mathrm{~V} . \Delta i_{L_{-} \text {Boost }}$ (The ripple current) is calculated as follows [30] (taken as $13 \%$ of the total current):

$$
\Delta i_{L-B o o s t}=0.13 I_{T C} \frac{V_{D C-l i n k}}{V_{I N}}
$$

The ripple of the output voltage as follows:

$$
\frac{\Delta V_{P V}}{V_{D C-\text { link }}}=0.253
$$

The PV array is a current source so a capacitor $\left(C_{P V}\right)$ is connected in parallel to its output, determined using Eq. (4) [30].

$$
C_{p v}=\frac{D_{448 V} V_{D C-l i n k}}{4 \Delta V_{P V} f_{s w}^{2} L_{B o o s t}} \cong 10 \mu F
$$

\subsection{DC-DC Buck Converter}

The buck converter shown in Fig. 6 [32] is composed of the voltage of the DC-link as an input source $\left(V_{D C \text {-link }}\right)$, buck inductor $\left(L_{B u c k}\right)$, buck capacitor $\left(C_{B u c k}\right)$, a diode $(D)$, $\operatorname{MOSFET}(S)$ as a switch and the output voltage $\left(V_{E V B}\right)$ as an EV battery voltage which the battery voltage of Tesla $S$ $100 \mathrm{D}$ cars is $350 \mathrm{~V}$.

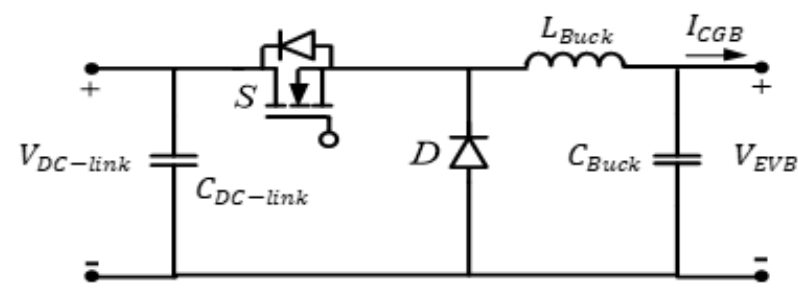

Figure 6. The Buck Converter diagram

The duty ratio is determined from Eq. (5).

$$
D_{\text {buck }}=\frac{V_{E V B}}{V_{D C-\text { link }}}=0.583
$$

\subsubsection{Design of Buck Inductor and Buck Capacitor}

The inductance for continuous current in the buck converter is calculated as follows [32]:

$$
L_{\text {buck }}=\frac{V_{D C-l i n k}-V_{E V B}}{\Delta i_{L-B u c k} f_{s w}}=96.15 \mu \mathrm{H}
$$

$\Delta i_{L-B u c k}$ (The ripple current) is calculated as follows (taken as $13 \%$ of the charge current):

$$
\Delta i_{L-B u c k}=0.13 I_{C G B}=65 \mathrm{~A}
$$

The output voltage ripple $\left(\Delta V_{E V B} / V_{E V B}\right)$ must not increase by $0.5 \%$. The buck capacitor is calculated using Eq. (7) [32].

$$
C_{B u c k}=\frac{1-D_{B u c k}}{8 L_{B u c k}\left(\frac{\Delta V_{E V B}}{V_{E V B}}\right) f_{s w}^{2}}=67.76 \mu F
$$

\subsection{The Bidirectional Converter}

To smooth power storage generated from off-grid systems during excess generated, the storage battery is provided as a backup service during electricity loss.

This paper suggests a bidirectional buck-boost converter, as shown in Fig. 7 [33] to control the storage and supply of power between the PV system and the battery bank as a result of the following advantages:

- It offers the most efficient solution with the smallest external components.

- It performs step-up or step-down of voltage using minimum components.

- It offers a lower operating duty cycle.

- It offers high efficiency across wide input and output voltage ranges.

- It is less expensive compared to most of the converters.

Two operation modes can be designed for the bidirectional converter based on the direction of the power flow: boost and buck modes. These modes are presented in detail in [33].

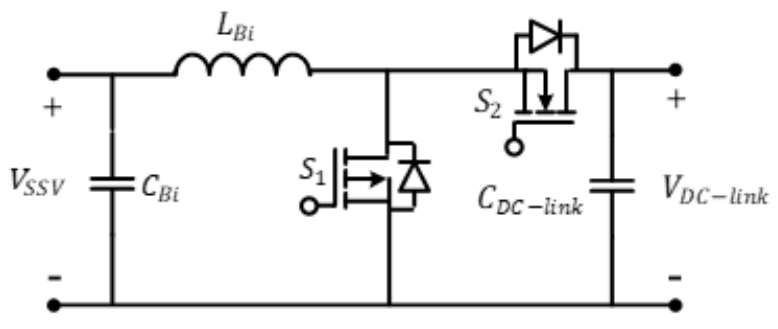

Figure 7. The Bidirectional Converter diagram

\subsubsection{The Component Design for the Bidirectional} Converter

Two values of the inductance $\left(L_{B i}\right)$ can be expressed as follows:

In Buck mode:

$$
L_{B i-B u c k}=\frac{V_{D C-\text { link }}-V_{S S V}}{\Delta i_{B i-B u c k} f_{S w}}=128.2 \mu \mathrm{H}
$$

$\Delta i_{B i-B u c k}$ (The ripple current) is calculated as follows (taken as $13 \%$ of the charge current):

$$
\begin{gathered}
\Delta i_{B i-B u c k}=0.13 I_{C G S}=39 A \\
L_{B i-\text { Boost }}=\frac{V_{S S V}\left(V_{D C-l i n k}-V_{S S V}\right)}{\Delta i_{B i-B o o s t} f_{S w} V_{D C-l i n k}}=34 \mu \mathrm{H}
\end{gathered}
$$

Where $\Delta i_{B i-B o o s t}$ (The ripple current) under the Boost mode is calculated as follows (taken as $13 \%$ of the charge current): 


$$
\Delta i_{B i-\text { Boost }}=0.13 I_{C G S} \frac{V_{D C-\text { link }}}{V_{S S V}}=97.5 \mathrm{~A}
$$

$L_{B i-B u c k}$ is greater than $L_{B i-B o o s t}$ so to make sure that the inductor current can operate during the continuous conduction mode (CCM) [33], the value of $L_{B i-B u c k}$ is chosen, i.e., $L_{B i}$ is equal to $128.2 \mu \mathrm{H}$.

Where $D_{B i-B o o s t}$ is the duty cycle under the Boost mode and calculated as follow:

$$
D_{B i-B o o s t}=1-\frac{V_{S S V}}{V_{D C-l i n k}}=0.33
$$

The DC-link capacitor $\left(C_{D C \text {-link }}\right)$ is calculated by Eq. (10) [33]. The output voltage ripple $\left(\Delta V_{E V B} / V_{D C-\text { link }}\right)$ must not increase by $0.5 \%$.

$$
C_{D C-\text { link }}=\frac{D_{B i-B o o s t}}{\left(\frac{V_{D C-l i n k}}{I_{C G B}}\right)\left(\frac{\Delta V_{E V B}}{V_{D C-l i n k}}\right) f_{s w}}=1375 \mu \mathrm{F}
$$

$C_{B i}$ is the capacitor on the battery bank side, consequently selecting $C_{D C-\text { link }}=C_{B i}=1375 \mu F$

\section{The Parameters Summary}

Table (3) presents a summary of the parameters that

\begin{tabular}{|c|c|c|}
\hline The parameter & The description & The value \\
\hline$E$ & The electric vehicle battery energy & $100 \mathrm{kWh}$ \\
\hline$P_{C h}$ & The required charger power of the EV battery & $300 \mathrm{KW}$ \\
\hline$t_{C h}$ & The required charger time of the EV battery & $20 \min$ \\
\hline$P_{P V}$ & The total PV array power & $600 \mathrm{~kW}$ \\
\hline$D O D$ & The depth of the battery bank discharge & 0.8 \\
\hline$V_{S S V}$ & Storage system voltage & $400 \mathrm{~V}$ \\
\hline$\eta_{B}$ & Battery bank efficiency & 0.85 \\
\hline$N_{C}$ & Days of autonomy & 4 days \\
\hline$B B C$ & Battery Bank Capacity & $1500 \mathrm{Ah}$ \\
\hline$N_{B S}$ & Number of batteries in series & 8 \\
\hline$N_{B p}$ & Number of batteries in parallel & 1 \\
\hline$N_{B t}$ & Total number of required batteries & 8 \\
\hline$P_{B K}$ & The battery bank power & $200 \mathrm{~kW}$ \\
\hline$V_{D C-l i n k}$ & DC-link Voltage & $600 \mathrm{~V}$ \\
\hline$I_{C G B}$ & The charge current required for the EV battery & $500 \mathrm{~A}$ \\
\hline$I_{C G S}$ & The charging current of the storage system & $300 \mathrm{~A}$ \\
\hline$I_{T C}$ & The total current after adding the system losses & $1000 \mathrm{~A}$ \\
\hline$N_{P}$ & The number of modules in parallel & 180 \\
\hline$N_{S}$ & The number of modules in series & 11 \\
\hline$N_{t}$ & The total number of modules & 1980 \\
\hline$f_{s w}$ & The switching frequency & $40 \mathrm{kHz}$ \\
\hline$L_{\text {Boost }}$ & The inductance of the boost converter & $16.3 \mu H$ \\
\hline$C_{D C-\text { link }}$ & The DC-link capacitor & $1375 \mu F$ \\
\hline$C_{p v}$ & The PV array capacitor & $10 \mu F$ \\
\hline$V_{E V B}$ & The EV battery voltage & $350 \mathrm{~V}$ \\
\hline$L_{B u c k}$ & The inductance of the buck converter & $96.15 \mu \mathrm{H}$ \\
\hline$C_{\text {Buck }}$ & The capacitor of the buck converter & $67.76 \mu F$ \\
\hline$L_{B i}$ & The inductance of the bidirectional converter & $128.2 \mu \mathrm{H}$ \\
\hline$C_{B i}$ & The bidirectional converter capacitor on the side of the battery pack & $1375 \mu F$ \\
\hline \multirow{2}{*}{ SOC $\%$} & The initial charge state of the battery bank & $80 \%$ \\
\hline & The initial charge state of the EV battery & $40 \%$ \\
\hline
\end{tabular}
were used and that were calculated.

Table 3. The summary of the parameters of the simulation 


\section{The Charge and Discharge Controller Modes}

The charging and discharging controller are used to perform power transfer from and to the battery bank. The stand-alone PV system with the battery bank using the bidirectional converter shown in Fig. 7 has four different control modes based on the magnitude of power provided by the PV array which relies on the temperature and irradiance.

Mode 1: The first control mode is operated when the generated $\mathrm{PV}$ power is less than the power demanded by the EV battery, i.e., $P_{P V}<P_{C h}$ and the charge state of the storage battery (SOC) is more than $40 \%$. In this mode, the bidirectional converter turns into the buck mode in which the controller gives a control signal to make switch $1\left(S_{1}\right)$ to be in a disconnected state and at the same time gives a control signal to make switch $2\left(S_{2}\right)$ to be in a connecting state. Storage batteries provide supplementary power through this mode.

Mode 2: The second control mode is operated when the generated $\mathrm{PV}$ power is less than the power demanded by the EV battery, i.e., $P_{P V}<P_{C h}$ and the charge state of the storage battery (SOC) is less than $40 \%$. The controller in this mode provides a control signal to make both of switch $1\left(S_{1}\right)$ and switch $2\left(S_{2}\right)$ to be in a disconnected state.

Mode 3: The third control mode is operated when the generated $\mathrm{PV}$ power is more than the power demanded by the EV battery, i.e., $P_{P V}>P_{C h}$ and the charge state of the storage battery (SOC) is less than $90 \%$ and more than $40 \%$. During this mode, the PV array not only provides the power to the EV battery under maximum power point enabled control, but also the surplus power produced by the PV array is used to charge the battery bank. The controller in this mode gives a control signal to make switch $1\left(S_{1}\right)$ to be in a connecting state and at the same time gives a control signal to make switch $2\left(S_{2}\right)$ to be in a disconnected state, i.e., the bidirectional converter turns into the boost mode.

Mode 4: The fourth control mode is operated when the generated $\mathrm{PV}$ power is more than the power demanded by the EV battery, i.e., $P_{P V}>P_{C h}$ and the charge state of the storage battery (SOC) is more than $90 \%$. In this mode, the $\mathrm{PV}$ array supplies power to the EV battery under maximum power point enabled control and it is also maintained that the charge state of the storage battery remains more than $90 \%$ through constant voltage charging so that the battery does not discharge itself. The controller in this mode provides a control signal to make both of switch $1\left(S_{1}\right)$ and switch $2\left(S_{2}\right)$ to be in a disconnected state. The flowchart in Fig. 8 illustrates the four operating modes.

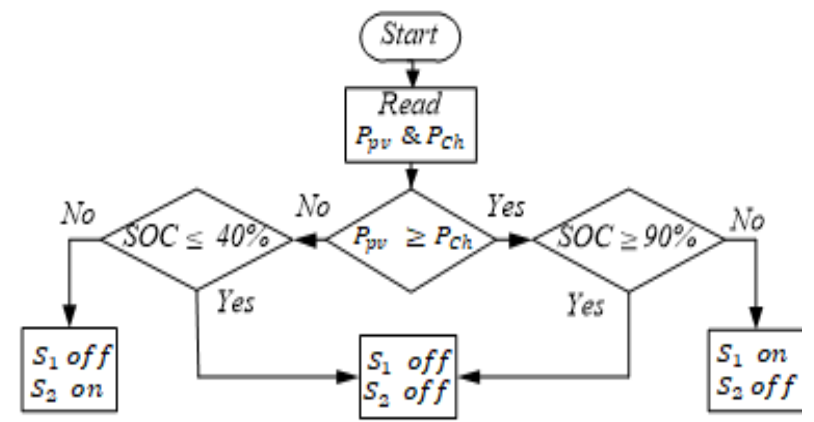

Figure 8. Flowchart of four operating modes

\subsection{The Logic Controller of the Charge and the Discharge}

Fig. 9 shows the logic controller of the charge and the discharge. Which $A, B, C$ are the control signals. $\bar{A}, \bar{B}, \bar{C}$ are the inverse of $A, B, C$ respectively.

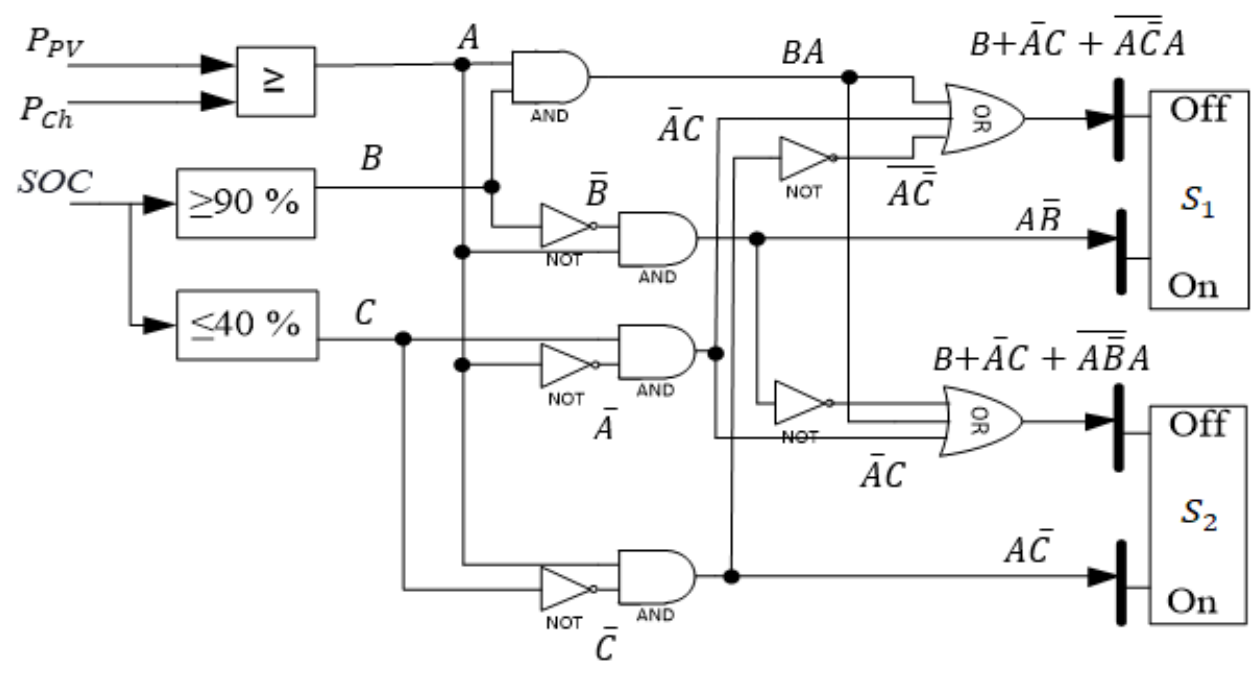

Figure 9. The logic controller of the charge and the discharge 


\section{Results and Comments}

The proposed charging station is shown in Fig. 4 is simulated using MATLAB, Simulink. The irradiance and temperature time-varying are input signals to the $\mathrm{PV}$ modules as described in Fig. 10 as follow:

The irradiance starts with zero value until the time 1.5 $\mathrm{sec}$, then gradually increases until equals $1000 \mathrm{~W} / \mathrm{m} 2$ at the time $2 \mathrm{sec}$. The temperature starts with $25^{\circ} \mathrm{C}$ until the time $2.2 \mathrm{sec}$, then gradually increases until equals $75^{\circ} \mathrm{C}$ at the time $2.5 \mathrm{sec}$.

Fig. 11 describes the discharging and charging modes as follows:

With no irradiance and at temperature $25^{\circ} \mathrm{C}$ until a time $1.5 \mathrm{sec}$, as shown in Fig 10, the battery bank power $\left(P_{B K}\right)$ provides the charging energy for the EV battery in which the battery bank is in the discharging mode. After a time $1.5 \mathrm{sec}$, the irradiance starts increasing and the PV array power starts increasing. By the time $2 \mathrm{~s}$, the battery bank power $\left(P_{B K}\right)$ decreases in which the battery bank charging mode starts. As noticed in Fig. 11, the power demanded by the EV battery $\left(P_{C h}\right)$ increases by increasing the $\mathrm{PV}$ array power.

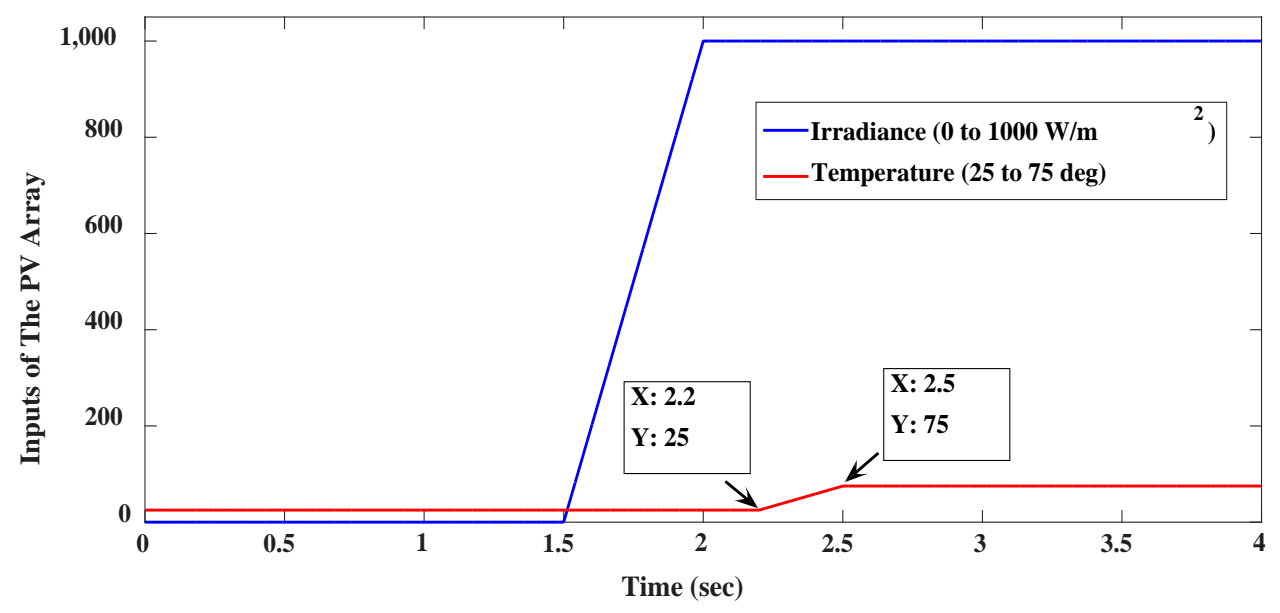

Figure 10. The PV array inputs

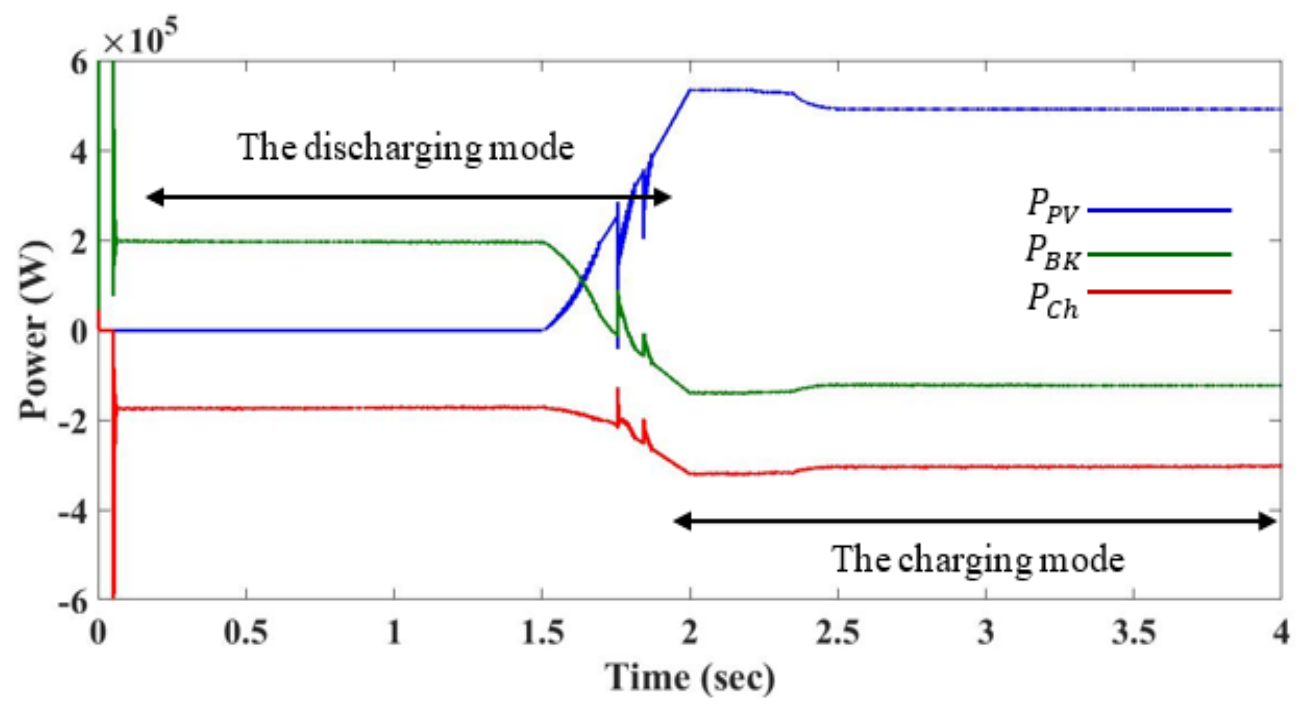

Figure11. The discharging and the charging modes of the battery bank 


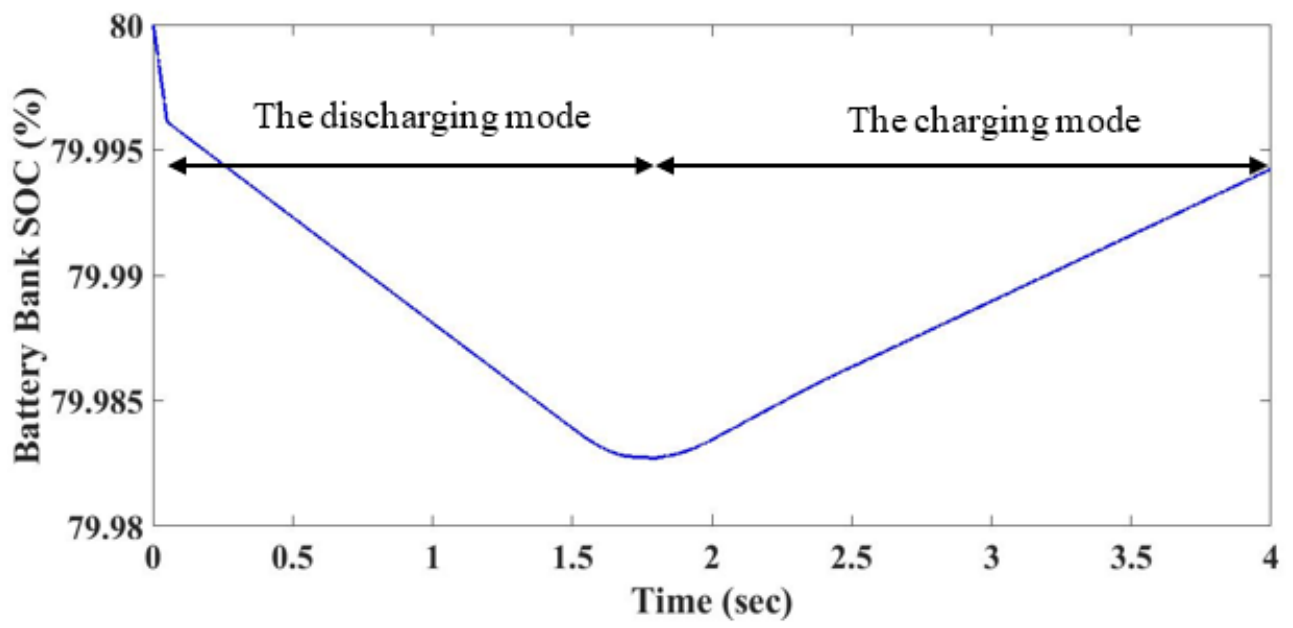

Figure 12. The SOC of the battery bank

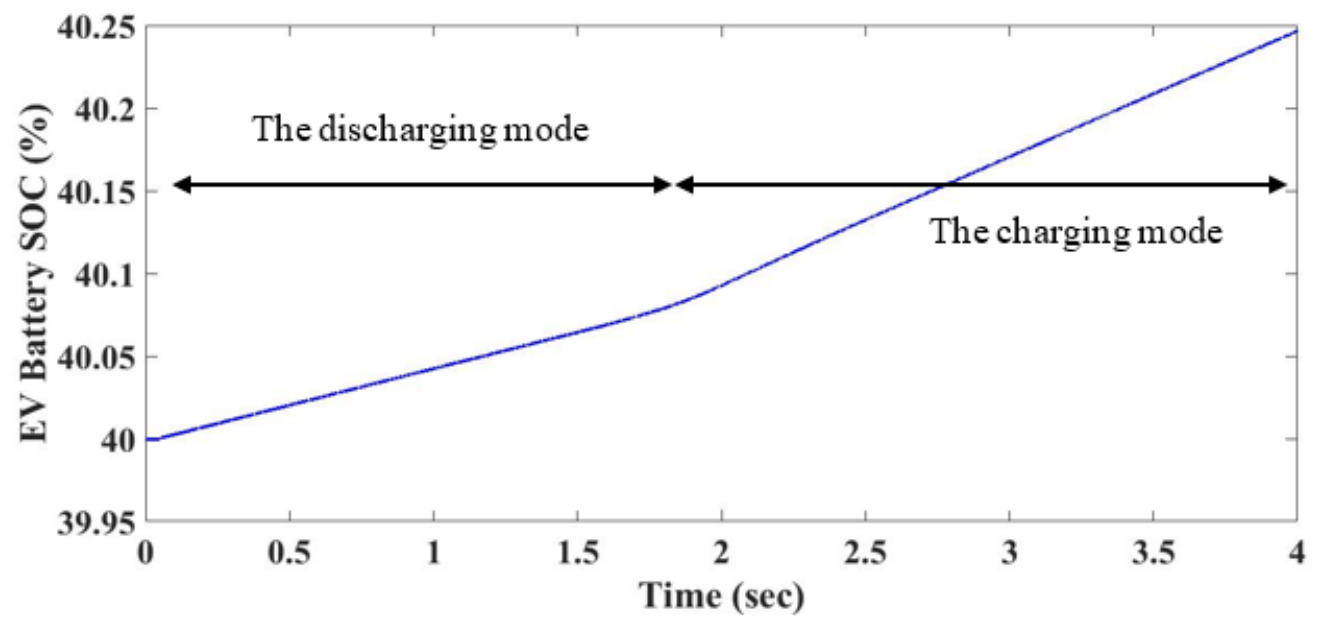

Figure 13. The SOC of the EV battery

Fig. 12 presents the SOC of the battery bank in the discharging and charging mode. The SOC of the EV battery is shown in Fig. 13.

It is observed in Fig. 12 that the SOC of the battery bank decreases with no solar radiation until the time 1.7 sec, and with the gradual increase of solar radiation, the battery bank begins to gradually enter the charging mode. It is also noted that the transition from the discharge mode to the charging mode is relatively slow. In Figure 13, it is observed that the SOC of the EV battery increases in all modes but in the charging mode, it increases faster.

\section{The Performance of the Lithium-ion Batteries and the Lead-Acid Batteries with the Proposed Charging Station}

In this section, the lead-acid batteries will be used instead of the lithium-ion batteries with the same rated capacity as well as the voltage rated to make a comparison between the performance of each type with the proposed charging station.

\subsection{The SOC of the Lithium-ion and the Lead-acid Batteries during the Charging and Discharging Mode}

The SOC of the lithium-ion and the lead-acid batteries during the charging and discharging mode are presented in Fig. 14. It is noted in Fig. 14 that lithium-ion batteries are deeper discharging than the lead-acid batteries while in charging mode the lead-acid batteries are faster charging than the lithium-ion batteries. The charging and discharging mode of the battery bank directly affects the charging time of the electric vehicle battery and also affects the power of the PV modules destined for the load, and this is what will be shown in the following sections. 


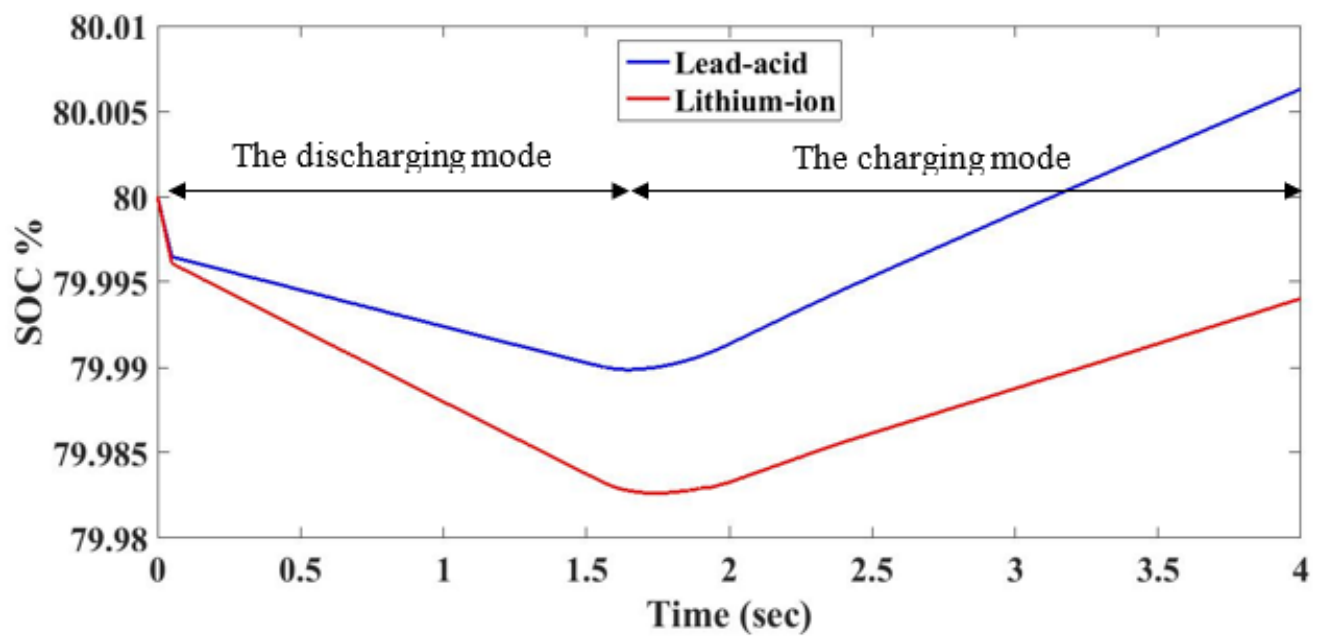

Figure 14. The SOC of the lithium-ion and the lead-acid batteries during the charging and discharging modes

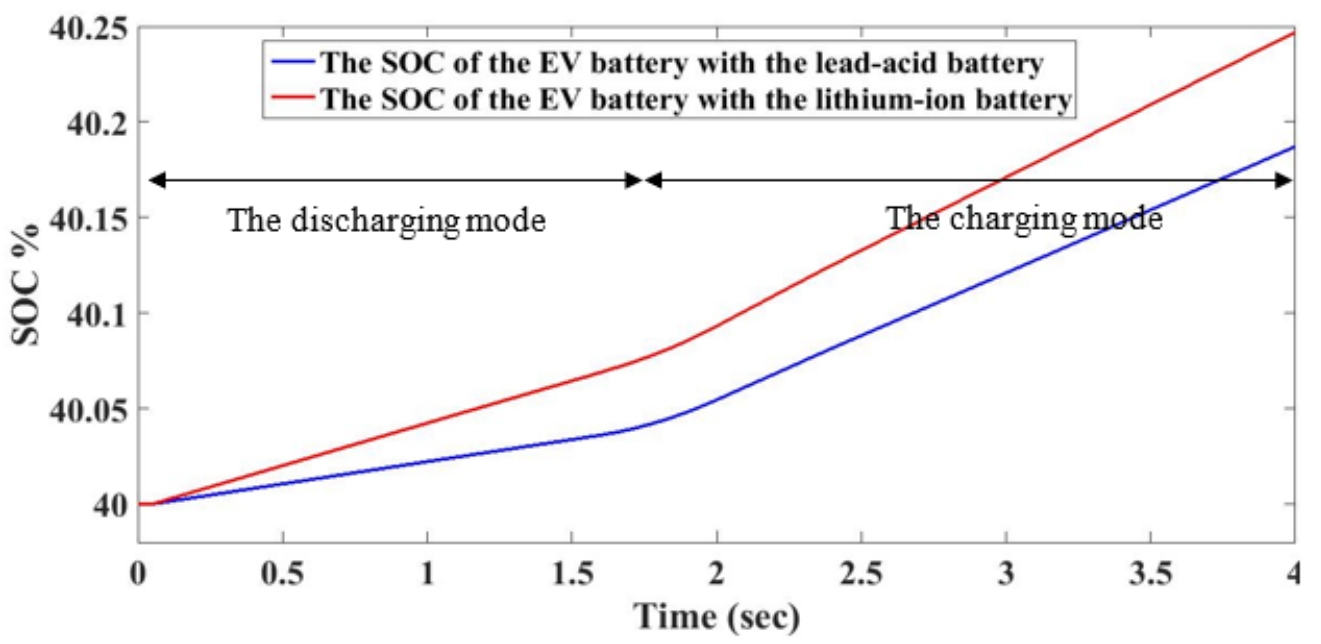

Figure 15. The SOC of the EV battery with the lithium-ion and the lead-acid batteries

\subsection{The SOC of EV Battery with the Lithium-ion and the Lead-acid Batteries}

From Fig. 15, it is clear that the EV battery is charging faster with the lithium-ion batteries. The charging time is important for charging the EV battery, so the choose the lithium-ion batteries as a back-up storage system for the stand-alone PV system is the best.

\subsection{PV Performance with the Lithium-ion and the Lead-acid Batteries}

From Fig. 16, it is evident that the PV modules provide the electric vehicle battery with greater charge power, in the presence of lead-acid batteries, in contrast, lithium-ion batteries help reduce the energy generated by the stand-alone PV system. For further clarification, Fig. 17 is a magnification of a section of Fig. 16 to demonstrate the difference between the power of the solar panels with both lithium-ion batteries and lead-acid batteries. 


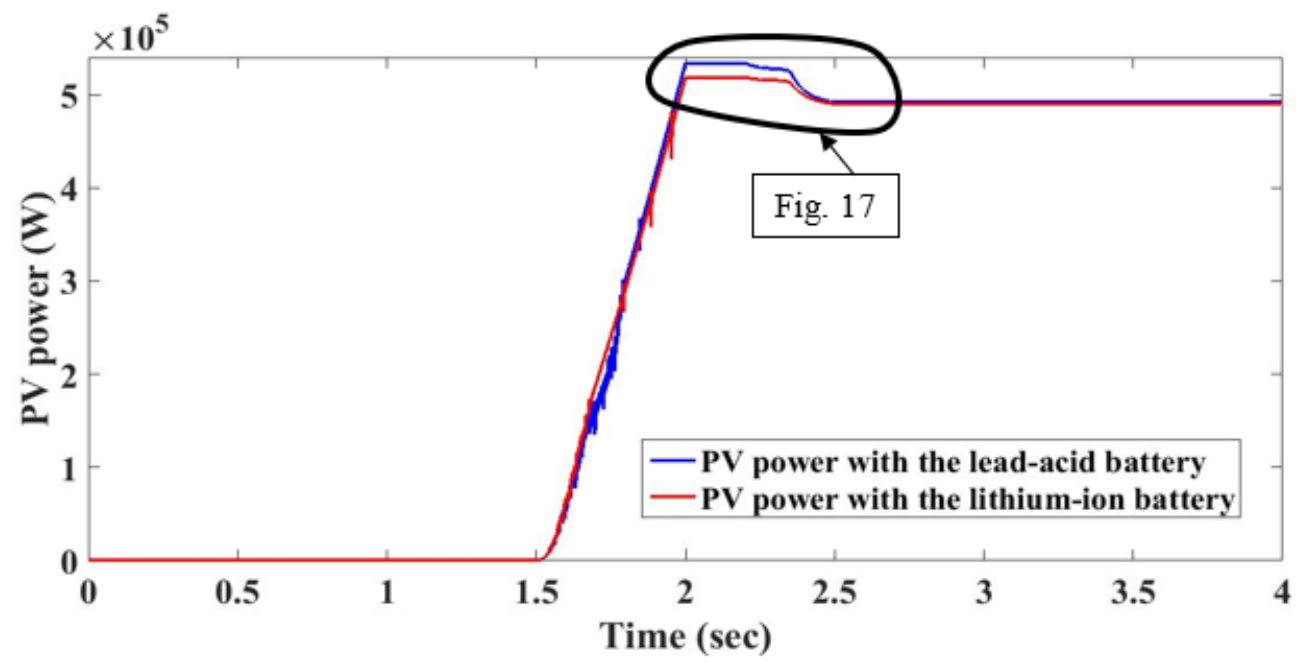

Figure 16. PV modules' performance with the lithium-ion and the lead-acid batteries

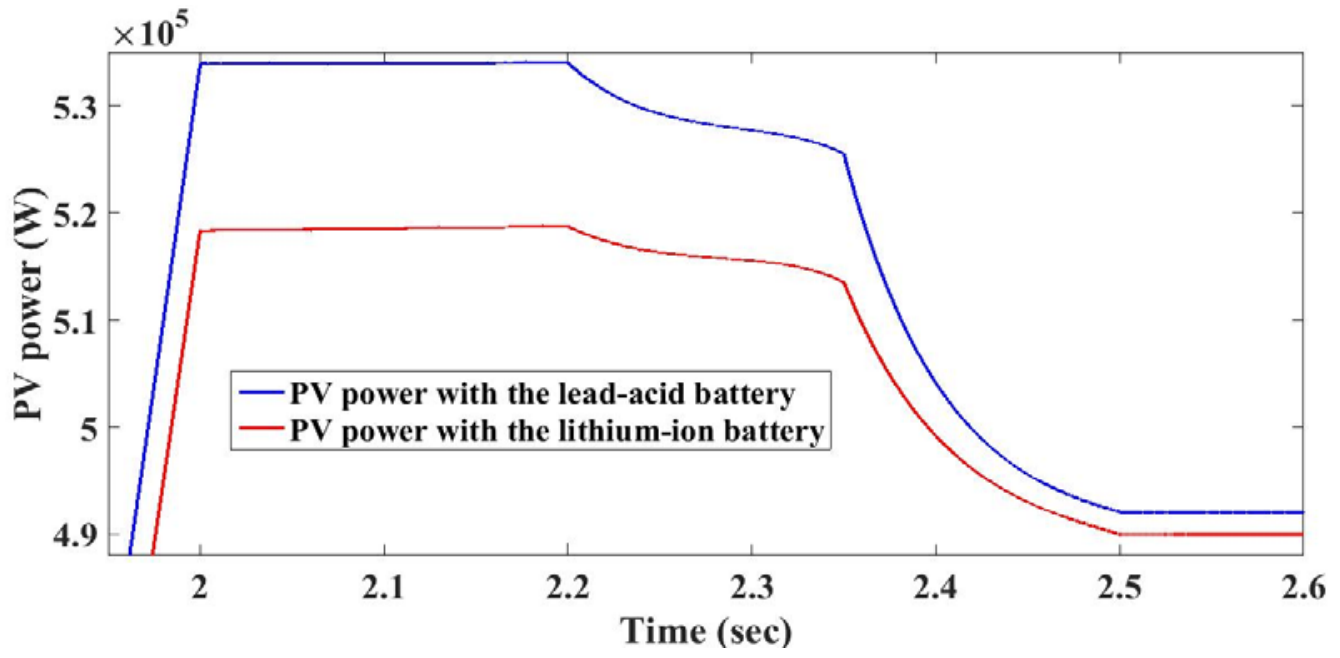

Figure 17. A zoom up of a section of Fig. 16

\section{The Proposed Charging Station Cost Estimation}

The cost estimation at this stage can present a powerful index of the proposed charging station's effectiveness and also determines if the decision of installing such a charging station practical or not. To complete the costing process, the design of the rest of the main charging station components must be performed, this is presented in the following section.

\subsection{Determination the System Protection Rating}

The PV modules in parallel need DC fuses to protect each module apart. DC fuse rating is calculated as follows:

$$
D C_{\text {fuse }}=I_{S C} * S F=5.95 * 1.25=7.4 \mathrm{~A}
$$

Which $S F$ is a safety factor. The nearest standard value for $7.4 A$ is10 $A$. The system needs $180 \mathrm{DC}$ fuses.

The modules in parallel are divided into 18 groups, each group contains 10 modules with CB for each group and its rating is calculated as follows:

$$
C B_{\text {group }}=I_{S C} * 10=5.95 * 10=59.5 \mathrm{~A}
$$

The closest standard value for $59.5 A$ is $63 A$. The system needs the number 18 units of the circuit breaker rating 63A.

The main circuit breaker rating for total PV modules' protection is calculated as follows:

$$
C B_{P V}=I_{S C} * N_{P}=5.95 * 180=1071 \mathrm{~A}
$$

The nearest standard value for $1071 \mathrm{~A}$ is $1250 \mathrm{~A}$.

The circuit breaker rating for boost converter protection is calculated as follows:

$$
C B_{\text {Boost }}=I_{\text {Boost }} * S F=1000 * 1.25=1250 \mathrm{~A}
$$

Thus the system needs the number 2 units of the circuit breaker rating $1250 \mathrm{~A}$. 
The buck converter current and the bidirectional converter current are the same (500 A), so the CB rating for buck converter protection and bidirectional converter protection is the same and is calculated as follows:

$$
C B_{\text {Buck }}=I_{\text {Buck }} * S F=500 * 1.25=625 \mathrm{~A}
$$

Thus the system needs the number 2 units of the circuit breaker rating $625 \mathrm{~A}$.

\subsection{The Number of Chassis and the Cables Sizes}

The chassis carries 4 panels, so the total number of the chassis is calculated as follows:

$$
N_{\text {chassis }}=\frac{N_{t}}{4}=495
$$

10.2.1. The Cables Sizes between the PV Modules and the Boost Converter

The wires between the PV modules in parallel and the boost converter must withstand the maximum current $\left(I_{S C}\right)$ produced by these modules; the wire cross-sectional area is given by,

$$
A_{P V-B o o s t}=\frac{\rho L_{P V-B o o s t} I_{S C}}{V_{d}}
$$

Let the length of the wire $\left(L_{P V-B o o s t}\right)=15 \mathrm{~m}$.

Where $\rho=$ resistivity of copper wire which was taken as $1.724 \times 10^{-8} \Omega \mathrm{m}$. The maximum DC wiring voltage drop $\left(V_{d}\right)$ for the off-grid system is $4 \%$ of the system voltage $\left(V_{D C-\text { link }}\right)$ [34]. It means that,

$$
A_{P V-B o o s t}=\frac{1.724 \times 10^{-8} \times 15 \times 5.96}{0.04 \times 600} \approx 10 \mathrm{~mm}^{2}
$$

The length of the wire cross-sectional area $10 \mathrm{~mm}^{2}=$ $2 * L_{P V-B o o s t} * N_{P}=5400 \mathrm{~m}$.

\subsubsection{The Cables Sizes between the Boost Converter and} the Buck Converter

The wires between the boost converter and the buck converter must withstand the boost converter current; the system needs 6 boost converters, each one has $100 \mathrm{~kW}$ and $200 \mathrm{~A}$ rated. Let the length of the wire $\left(L_{\text {Boost }- \text { Buck }}\right)=5 \mathrm{~m}$. The wire cross-sectional area is given by Eq (12) as follows:

$$
A_{\text {Boost-Buck }}=\frac{\rho L_{\text {Boost-Buck }} I_{\text {Boost }}}{V_{d}}
$$

It means that,

$$
A_{\text {Boost-Buck }}=\frac{1.724 \times 10^{-8} \times 5 \times 200}{0.04 \times 600} \approx 10 \mathrm{~mm}^{2}
$$

The length of the wire cross-sectional area $10 \mathrm{~mm}^{2}$ between the boost converter and the buck converter $=$ $2 * L_{\text {Boost-Buck }} * 6=60 \mathrm{~m}$.

Thus, the total length of the wire cross-sectional area $10 \mathrm{~mm}^{2}=5400+60=5460 \mathrm{~m}$.
10.2.3. The Cables Sizes between the Boost Converter and the Battery Bank

Let the length of the wire $\left(L_{\text {Boost-Batt }}\right)=5 \mathrm{~m}$, the wires between the boost converter and the battery bank must withstand the bidirectional converter current $\left(I_{C G B}\right)$; The wire cross-sectional area is given by Eq (13) as follows:

$$
A_{\text {Boost-Batt }}=\frac{\rho L_{\text {Boost-Batt } I_{C G B} \times S F}}{V_{d}}
$$

It means that,

$$
\begin{aligned}
A_{\text {Boost-Batt }} & =\frac{1.724 \times 10^{-8} \times 5 \times 500 \times 1.25}{0.04 \times 600} \\
& \approx 25 \mathrm{~mm}^{2}
\end{aligned}
$$

The length of the wire cross-sectional area $25 \mathrm{~mm}^{2}$ between the boost converter and the battery bank = $2 * L_{\text {Boost-Battery }}=10 \mathrm{~m}$.

10.2.4. The Cables Sizes between the Buck Converter and the EV's Battery

The wires between the buck converter and the EV's battery must withstand the buck converter current; the system needs 3 buck converters, each one has $100 \mathrm{~kW}$ and $100 \mathrm{~A}$ rated. Let the length of the wire $\left(L_{B u c k-E V}\right)=3 \mathrm{~m}$. The wire cross-sectional area is given by Eq (14) as follows:

$$
A_{B u c k-E V}=\frac{\rho L_{B u c k-E V} I_{b u c k} x \text { safety factor }}{V_{d}}
$$

It means that,

$$
A_{\text {Buck-EV }}=\frac{1.724 \times 10^{-8} \times 3 \times 100 \times 1.25}{0.04 \times 400} \approx 4 \mathrm{~mm}^{2}
$$

The length of the wire cross-sectional area $4 \mathrm{~mm}^{2}$ between the buck converter and the EV's battery = $2 * L_{\text {Buck-EV }} * 3=18 \mathrm{~m}$.

Table (4) presents a summary of the proposed charging station components and their prices. The PV module price is estimated according to [35]. The other components are estimated according to [36].

\subsection{Determination of the Payback Period}

Let the proposed charging station is located in a remote area where electricity tariff is US\$ $0.23 / \mathrm{kWh}$. The equivalent sun hours (ESH) in this area is 6 hours. Then: Annual saving $=$ Total number of $\mathrm{PV}$ modules $\left(N_{t}\right) x$ module peak power $\left(P_{\max }\right)$ in kW $x$ ESH $x 365$ days $x$ electricity tariff.

It means that,

The annual saving $=\begin{array}{lllllllll}1980 & x & 0.305 & x & 6 & \times & 365 & x\end{array}$ $0.23=$ US\$ 304185 saving per year.

From Table (4), the grand total cost is US\$ 315040. Then:

Payback period $=$ US\$ 315040/ US\$ $304185=1.04$ year. 
Table 4. Details on costing the proposed charging station components

\begin{tabular}{|c|c|c|c|c|}
\hline The component & The rated & The number of units & The unit price (US\$) & The total price (US\$) \\
\hline PV module & $305 \mathrm{~W}$ & 1980 & 95 & 188100 \\
\hline MPPT & $100 \mathrm{~kW}$ & 6 & 2500 & 15000 \\
\hline Boost Converter & $100 \mathrm{~kW}$ & 6 & 1699 & 10194 \\
\hline Buck Converter & $100 \mathrm{~kW}$ & 3 & 2500 & 7500 \\
\hline Bidirectional Converter & $100 \mathrm{~kW}$ & 3 & 2500 & 7500 \\
\hline Storage Battery & $200 \mathrm{Ah}$ & 8 & 1000 & 8000 \\
\hline EV charging controller & $100 \mathrm{~A}$ & 5 & 165 & 825 \\
\hline DC fuse & $10 \mathrm{~A}$ & 180 & 3 & 540 \\
\hline Circuit Breaker & $63 \mathrm{~A}$ & 18 & 35 & 630 \\
\hline Circuit Breaker & $1250 \mathrm{~A}$ & 2 & 360 & 720 \\
\hline Circuit Breaker & $625 \mathrm{~A}$ & 2 & 140 & 280 \\
\hline Cable & $10 \mathrm{~mm}^{2}$ & $5460 \mathrm{~m}$ & 1.5 & 8190 \\
\hline Cable & $25 \mathrm{~mm}^{2}$ & $10 \mathrm{~m}$ & 2 & 20 \\
\hline Cable & $4 \mathrm{~mm}^{2}$ & 18 & 1 & 18 \\
\hline Chassis & & 495 & 51 & 25245 \\
\hline \multicolumn{4}{|c|}{ Total estimated cost (TEC) } & 272762 \\
\hline \multicolumn{4}{|c|}{ Carriage and freight (C \& F) (Assume 10\% of TEC) } & 27276 \\
\hline \multicolumn{4}{|c|}{ Contingency (Assume 5\% of subtotal for (TEC + C\& F)) } & 15002 \\
\hline \multicolumn{4}{|c|}{ Grand Total (TEC + C \& F+ Contingency) } & 315040 \\
\hline
\end{tabular}

\section{Conclusions}

A charging station using the stand-alone PV system with an energy storage system to charge an EV battery has been successfully designed and simulated in this paper. The MPPT controller with an Incremental Conductance algorithm has been applied. A charge and discharge stages using the bidirectional converter of the battery energy storage was also successfully modeled and simulated. A logic controller for the bidirectional converter has also been designed and simulated. The results have proven the logic controller's effectiveness with the bidirectional controller. A comparison between the lithium-ion and the lead-acid batteries as a power storage system for the proposed charging station has been achieved. Using lithium-ion batteries is better than the lead-acid for the proposed charging station, in which the charging time of the EV battery is less. A proposed charging station cost estimation has been performed. Lastly, the model, in general, has been successfully simulated in Matlab, Simulink and satisfactory simulation results have also been achieved. Although the use of a bidirectional converter can adjust the charging and discharging of the battery pack and reduce the amount of battery usage; however, when the load current changes instantaneously, the battery needs to quickly provide energy to the load. Will the existence of the converter cause resistance to the speed of energy supply? This point needs to be clearly studied in future work. In this work the results were presented only in simulation; however, it is recommended in future work that experimental results should be added to compare between the simulation and the practice.

\section{REFERENCES}

[1] J. A. P. Lopes, F. J. Soares, P. M. R. Almeida, "Integration of Electric Vehicles in the Electric Power System", in Proceedings of the IEEE, vol. 99, no. 1, pp. 168-183, 2011.

[2] Albanese, Lorenzo \& Ciriminna, Rosaria \& Meneguzzo, Francesco \& Pagliaro, Mario. (2015). The impact of electric vehicles on the power market. Energy Science \& Engineering. 3. 10.1002/ese3. 72.

[3] A. S. Bin Humayd and K. Bhattacharya, “A Novel Framework for Evaluating Maximum PEV Penetration into Distribution Systems,” IEEE Trans. Smart Grid, vol. 9, no. 4, pp. 1-1, Jul 2018.

[4] K. Clement-Nyns, E. Haesen and J. Driesen, "The Impact of Charging Plug-In Hybrid Electric Vehicles on a Residential Distribution Grid”, IEEE Transactions on Power Systems, vol. 25, no. 1, pp. 371-380, 2010.

[5] K. Qian, C. Zhou, M. Allan, Y. Yuan, "Modeling of Load Demand Due to EV Battery Charging in Distribution Systems”, IEEE Transactions on Power System, vol. 26, pp. 802-810, 2011.

[6] F. Marra, C. Træholt, E. Larsen and Q. Wu, "Average Behavior of Battery-Electric Vehicles for Distributed 
Energy Studies”, IEEE Innovative Smart Grid Technology Conference, 2010.

[7] Van Roy J, Leemput N, Geth F, Salenbien R, Buscher J, Driesen J. Apartment building electricity system impact of operational electric vehicle charging strategies. IEEE Trans Sustain Energy 2013;5:264-72.

[8] R. C. Leou, C. L. Su, and C. N. Lu, "Stochastic analyses of electric vehicle charging impacts on the distribution network,” IEEE Trans. Power Syst., vol. 29, no. 3, pp. 10551063, May 2014

[9] S. Shafiee, M. Fotuhi-Firuzabad, and M. Rastegar, "Investigating the Impacts of Plug-in Hybrid Electric Vehicles on Power Distribution Systems,” IEEE Trans. Smart Grid, vol. 4, no. 3, pp. 1351-1360, Sep 2013.

[10] C. B. Harris and M. E. Webber, "The impact of vehicle charging loads on frequency regulation procurements in ERCOT,” in ISGT 2014. IEEE, Feb 2014, pp. 1-5.

[11] Kelman, C. Supporting increasing renewable energy penetration in Australia the potential contribution of electric vehicles. In: Proceedings of 20th Australasian university power engineering conference (AUPEC); 2010. p. 1-6.

[12] E. Sortomme, M. M. Hindi, S. D. J. MacPherson, and S. S. Venkata, "Coordinated Charging of Plug-In Hybrid Electric Vehicles to Minimize Distribution System Losses," IEEE Trans. Smart Grid, vol. 2, no. 1, pp. 198-205, Mar 2011.

[13] M. Akmal, A. Jawad and A. Al Tarabesheh, "Design and Simulation Solar Grid-Connected Charger for Electrical Vehicles", UKSim AMSS 20th International Conference on Modelling \& Simulation 2018

[14] A. R. Bhatti and Z. Salam, "Photovoltaic (PV) Charging of Electric Vehicle (EV)", in Conference Electrical Engineering Research Colloquium (EERC-2013), At Faculty of Electrical Engineering, University Technology Malaysia (UTM), Malaysia, Vol. 1, 2013.

[15] M.E. Glavin, Paul K.W. Chan, S. Armstrong, and W.G Hurley," A Stand-alone Photovoltaic Supercapacitor Battery Hybrid Energy Storage System", IEEE, International Power Electronics and Motion Control Conference (EPE-PEMC 2008), pp. 1688-1695.

[16] Rashed, Ghamgeen I. et al. “Applicability Study of Battery Charging Stations in Off-Grid for Rural Electrification - the case of Rwanda.” 2019 International Conference on Power Generation Systems and Renewable Energy Technologies (PGSRET) (2019): 1-6.

[17] Ishaq M., Ibrahim U.H., Abubakar, H. "Design of an Off Grid Photovoltaic System: A Case Study of Government Technical College, Wudil, Kano State”, International Journal of Scientific \& Technology Research, ISSN 2277-8616, 2(12), December 2013, 172-181.

[18] T. Morgan, "Smart grids and electric vehicles: Made for each other?", Summit Int. Transport Forum, on Seamless Transport: Making Connections, Leipzig, Germany, 2-4 may 2012, discussion paper no. 2012-02, OECD.

[19] Abdelfatah Alia, David Raisz, Karar Mahmoud. " Voltage fluctuation smoothing in distribution systems with RES considering degradation and charging plan of EV batteries ", Electric Power Systems Research. Volume 176, November
2019, 105933, 1-16.

[20] Jha, M.; Blaabjerg, F.; Khan, M.A.; Kurukuru, V.S.B.; Haque, A. Intelligent Control of Converter for Electric Vehicles Charging Station. Energies 2019, 12, 2334.

[21] C. H. Dharmakeerthi, N. Mithulananthan and T. K. Saha, "Modeling and planning of EV fast charging station in power grid," 2012 IEEE Power and Energy Society General Meeting, San Diego, CA, 2012, pp. 1-8, doi: 10.1109/PESGM.2012.6345008.

[22] Vazquez, S., Lukic, S., Galvan, E., Franquelo, L., Carrasco, J., 2010. Energy storage systems for transport and grid applications. IEEE Trans. Ind. Electron. 57 (12), 3881-3895.

[23] X. Li, D. Hui and X. Lai, "Battery Energy Storage Station (BESS)-Based Smoothing Control of Photovoltaic (PV) and Wind Power Generation Fluctuations," in IEEE Transactions on Sustainable Energy, vol. 4, no. 2, pp. 464-473, April 2013, doi: 10.1109/TSTE.2013.2247428.

[24] H. Keshan, J. Thornburg and T. S. Ustun, "Comparison of lead-acid and lithium ion batteries for stationary storage in off-grid energy systems," 4th IET Clean Energy and Technology Conference (CEAT 2016), Kuala Lumpur, 2016, pp. 1-7. doi: 10.1049/cp.2016.1287

[25] Xu, Ling, Miao, Zhixin, Fan, Lingling, 2012. Control of a battery system to improve the operation of a Microgrid. In: Proc. IEEE on Power and Energy Society General Meeting held in San Diego, California, USA, During 22-26 July, pp. $1-8$.

[26] Dogger, J., Roossien, B., Nieuwenhout, F., 2011. Characterization of li-ion batteries for intelligent management of distributed grid-connected storage. IEEE Trans. Energy Convers. 26 (1), 256-263.

[27] J. Ning, J. Zeng and X. Du, "A Four-port Bidirectional DC-DC Converter for Renewable Energy-Battery-DC Microgrid System," 2019 IEEE Energy Conversion Congress and Exposition (ECCE), Baltimore, MD, USA, 2019, pp. 6722-6727, doi: 10.1109/ECCE.2019.8912185.

[28] Mirza Mursalin Iqbal, Kafiul Islam," Design and Simulation of A PV System With Battery Storage Using Bidirectional DC-DC Converter Using Matlab Simulink" International Journal of Scientific \& Technology Research Vol. 6, ISSUE 07, July 2017

[29] Unwaha, J.I, Jones, N. D. Musa, A.J. "Design of Off-Grid Solar Photovoltaic (PV) System for Cottage Hospital", Journal of Energy Technologies and Policy Vol.6, No.5, 2016.

[30] B. Yang, W. Li, Y. Zhao and X. He, "Design and Analysis of a Grid-Connected Photovoltaic Power System," in IEEE Transactions on Power Electronics, vol. 25, no. 4, pp. 992-1000, April 2010, doi: 10.1109/TPEL.2009.2036432.

[31] Garg, R. Singh, A. Gupta, S. "PV cell models and dynamic simulation of MPPT trackers in MATLAB" Computing for Sustainable Global Development (INDIA Com), 2014 International Conference on DOI: 10.1109/IndiaCom.2014. 6828003 Publication Year: 2014, Pages: 6-12

[32] Naeim S. "Design of a DC/DC buck converter for ultra-low power applications in 65nm CMOS Process", Master's thesis, Linköping University, 2012. 
[33] Kuei-Hsiang C., Ming-Chang T., Chun-Hao H., [34] National Electrical Code (NEC, 2005) Yang-Guang L. Liang-Chiao H. "Design and Implementation of a Bidirectional DC-DC Converter for Stand-Alone Photovoltaic Systems", International Journal of Computer, Consumer and Control (IJ3C), Vol. 2, No.3 (2013).

[35] https://www.ebay.com/itm/SunPower-SPR-305-WHT-U-30 5-watt-54-volt Solar Panel

[36] https://www.alibaba.com 